\title{
Examination of the Relationship between Organizational Stress and Employee Performance: A Research on Staff Working on Provincial Directorate of Youth and Sports
}

\author{
Ali Gurel Goksel ${ }^{1}$, Cagdas $\mathrm{Caz}^{2}$, Omer Faruk Yazici ${ }^{3} \&$ Huseyin Can Ikizler ${ }^{2}$ \\ ${ }^{1}$ Faculty of Sports Science, Mugla Sitki Kocman Universtiy, Mugla, Turkey \\ ${ }^{2}$ Faculty of Sports Science, Marmara Universtiy, Istanbul, Turkey \\ ${ }^{3}$ Gaziosmanpasa Universtiy, Tokat, Turkey \\ Correspondence: Ali Gurel Goksel, Mugla Sitki Kocman Universtiy, Faculty of Sports Science, 48000, Mugla, \\ Turkey. Tel: 90-531-551-3333. E-mail: aligoksel@mu.edu.tr
}

Received: December 1, 2016

Accepted: December 25, 2016 Online Published: January 3, 2017

doi:10.5539/jel.v6n1p322

URL: http://dx.doi.org/10.5539/jel.v6n1p322

A short version of this article was presented at the 14th International Sport Sciences Congress, 01st-04th November, 2016 Belek-Antalya, Turkey.

\begin{abstract}
The purpose of this research is to study the relation between the level of organizational stress at the staff of the Youth Services and Sports Provincial Directorate and their performance. The study group of research, Istanbul province in the Uskudar district officials operating in the Youth Services and Sports Provincial Directorate constitute a total of 96 staff, including 36 women and 60 men. In this research, "Job Strain Questionnaire Scale" that was developed firstly by Theorell et al. (1988) and adapted to Turkish by Yildirim et al. (2011) together with "Employee Performance Scale" that was developed by Kirkman and Rosen (1999) and adapted to Turkish by Col (2008) were used to collect data. In the evaluation of data as statistical analyzes; descriptive statistics, for independent groups t-test, one way analysis of variance (Anova) and Pearson Correlation test was used to determine the relationship between the dependent variables. As a result of the research; participants' employee performance showed significant differences according to marital status variables, there were no significant differences for organizational stress. In addition, there were no significant relationships between employee performance and organizational stress of the employees were determined.
\end{abstract}

Keywords: youth services and sports, staff, organizational stress, employee performance

\section{Introduction}

Social units have emerged as a consequence of organization. Therefore, each social unit displays an organization characteristic (Basaran, 1984; Yildirim, Tasmekepligil, Uzum, \& Bulut, 2011). Organization is a community that is constituted by people or institutions coming together for a common purpose or service. Organizations are social system and founded on the basis of reciprocal interest (Baransel, 1993; Koc, 1994; Ilgar, 1996). The importance of human factor has been increased to conduct sporting events, contests and sport facilities systematically, and provide services neatly in provincial directorate of youth and sports that displays organizational structure and field services affiliated to center. The staff working in this institution can have some psychological problems as a consequence of intense work pressure and the fatigue of everyday life (Bastug, Pala, Kumartasli, Gunel, \& Duyan, 2016). Stress, one of these problems, according to Daft (1991), is defined as physical and emotional reactions caused by problematic conditions such as imposition, oppression and uncertainty. The concept of organizational stress can be defines as physical and emotional reactions caused when the requirement of job can not meet the capacity, ability and needs of the worker (Cicei, 2012; Arrington, 2008; Blaug, Kenyon, \& Lekhi, 2007).

There are many factors on which organizational stress can have impact. One of these factors is the performance of workers (staff) display. Performance is the serving a purpose degree of conducting events in a specified time (Akal, 1992). The performance of workers is important in terms of effectiveness, success and performance of the 
organization. Moreover, researchers like Campell state that performance is not only a result of the event but also it is the event itself. Campell characterizes performance as measurable and proper behaviors according to contribution level of workers to organizational purposes (Suliman, 2001). In the light of the information about organizational stress and employee performance, it can be suggested that these two concepts are important in terms of employee (workers). It is a stubborn fact that employee exposed to stress will have problems in their everyday life and that the performance will be effected negatively. When researches into these concepts are examined, some researchers have conducted studies into organizational stress (Kristiansen, Halvari, \& Roberts, 2012; Uzum, Mirzeoglu, Polat, \& Akpinar, 2013; Kristiansen, Murphy, \& Roberts, 2012; Fletcher \& Hanton, 2003; Didymus \& Fletcher, 2014) and some have conducted studies into employee performance (Col, 2008; Yildiz, Dagdeviren, \& Cetinyokus, 2008; Ozutku, Agca, \& Cevrioglu, 2008; Yilmaz \& Karahan, 2010; Turunc \& Celik, 2010; Onay, Suslu, \& Kilci, 2011; Dogu \& Yilmaz, 2015; Cakici \& Dogan, 2014; Ogut \& Kaplan, 2015).

In our country, provincial directorate of youth and sports and field services of it have important role to provide sport services, coordinate sport events and train successful athletes. It can be said that stress, one of the most factors effecting staff working in these institutions, is an important issue that should be pursued and discoursed because it is thought that the concept of organizational stress has negative impact on employee performance. Besides, organizational stress can cause employee to estrange from their everyday life and influence their performance negatively. At this point, it can be thought that the results of this study become important in terms of employee to be aware of stress they have at work and how this stress can influence their performance. This study can contribute the literature because it provides reference for the organizational stress and employee performance researches conducted in all fields, especially in sport sciences. In the light of this information, the aim of this study is to examine the relationship between organizational stress and employee performance in provincial directorate of youth and sports. For this purpose, following questions will be answered: (1) What level is the organizational stress and employee performance of the staff in provincial directorate of youth and sports?

(2) Are there any differences between genders in terms of the organizational stress and employee performance of the staff in provincial directorate of youth and sports?

(3) Are there any differences between marital status in terms of the organizational stress and employee performance of the staff in provincial directorate of youth and sports?

(4) Are there any differences between educational statuses in terms of the organizational stress and employee performance of the staff in provincial directorate of youth and sports?

(5) Are there any differences between monthly incomes in terms of the organizational stress and employee performance of the staff in provincial directorate of youth and sports?

(6) Are there any differences between age categories in terms of the organizational stress and employee performance of the staff in provincial directorate of youth and sports?

(7) Is there a significant relationship between organizational stress and employee performance of the staff in provincial directorate of youth and sports?

\section{Method}

\subsection{The Method of the Study}

The study was conducted with relational scanning model, which is one of the general scanning models. "Scanning Models are the research approaches that aim to describe an existing or past situation as is" (Karasar, 2000).

\subsection{The Universe and the Sampling of the Study}

36 female (37.5\%) and 60 male (62.5\%) working in Istanbul Provincial Directorate of Youth and Sports in 2016 consisted the sample group.

\subsection{Data Collection Tool}

"Organizational Stress Scale", "Employee Performance Scale" and Personal Information Form developed by the researchers have been used for data collection. Organizational Stress Scale was developed by Theorell, Perski, and Åkerstedt (1988) and adapted to Turkish by Yildirim et al. (2011). The scale consists of four subscales (Social Support, Work Load, Skill Usage and Decision-making) and 14 items, and it is likert type scale (Always:5, Mostly:4, Sometimes:3, Rarely:2, Never:1).

Employee Performance Scale was developed by Kirkman and Rosen (1999), and adapted to Turkish by Col (2008). The scale is one-dimensional and has 4 items ( $5=$ Strongly agree, $4=$ Agree, $3=$ Undecided, $2=$ not agree, 
1=strongly not agree). Personal Information Form includes variables such as gender, marital status, educational status, monthly income, and age.

Instruments were conducted to employees in working time. Before conducting the scale, detailed information about the scales was given to employees. The scales were conducted to volunteer participants. 96 of 109 raw data were collected after checking data if any wrong answers were given and computerized for the analysis.

\subsection{The Analysis of Data}

Collected data was analyzed by using descriptive test, independent $t$ test for two groups, one-way ANOVA, Tukey test and Pearson Correlation test. It was decided whether data provided the precondition of parametric tests by examining the results of Skewness and Kurtosis values and Levene test (Buyukozturk, 2012). Kline (2005) has suggested that data displays normal distribution when Kurtosis is between -3 and +3 ; Skewness is between -10 and +10 . Additionally, Equality of variances assumption is ensured when $F$ value, calculated with Levene test, is not significant ( $>00.05$ ) (Cokluk, Sekercioglu, \& Buyukozturk, 2010). It was reported that analysis ensured the parametric test assumption of the data. Cronbach's Alpha internal consistency coefficient was calculated for the reliability of scales. Internal consistency coefficients of Organizational Stress Scale and Employee Performance Scale were found to be 0.81 and 0.80, respectively.

\section{Results}

Table 1. The range of scale scores

\begin{tabular}{lllll}
\hline Scale & $\mathrm{N}$ & $\mathrm{X} \pm \mathrm{SD}$ & Skewness & Kurtosis \\
\hline Organizational Stress & 96 & $3.20 \pm 0.35$ & -0.18 & -0.35 \\
Employee Performance & 96 & $4.35 \pm 0.58$ & -1.07 & 2.18 \\
\hline
\end{tabular}

Arithmetic mean scores of employees reported in Organizational Stress Scale and Employee Performance Scale were found to be $3.20( \pm 0.35)$ and $4.35( \pm 0.58)$, respectively. When Skewness and Kurtosis values were examined, data collected from employees displayed normal distribution (Table 1).

Table 2. Differences between genders in terms of organizational stress and employee performance

\begin{tabular}{lcccc}
\hline \multirow{2}{*}{ Scale } & Female $(n=36)$ & Male $(n=60)$ & $\mathrm{t}$ & $\mathrm{p}$ \\
& $\mathrm{X} \pm \mathrm{SD}$ & $\mathrm{X} \pm \mathrm{SD}$ & -0.99 & 0.32 \\
Organizational Stress & $3.20 \pm 0.39$ & $3.23 \pm 0.33$ & 1.16 & 0.24 \\
Employee Performance & $4.44 \pm 0.54$ & $4.30 \pm 0.60$ & & \\
\hline
\end{tabular}

No significant differences were found between genders in terms of organizational stress (tOS=-.99, $\mathrm{p}>0.05$ ) and employee performance $(\mathrm{tEP}=1.16, \mathrm{p}>0.05)$ (Table 2). The Organizational Stress scores of males and females were found to be 3.23, 3.20, respectively. The Employee Performance scores of males and females were found to be 4.30, 4.44, respectively. Females reported higher scores than males in terms of employee performance.

Table 3. Differences between Marital Statuses in terms of organizational stress and employee performance

\begin{tabular}{lcccc}
\hline Scale & Married $(n=66)$ & Single $(n=30)$ & & $\mathrm{p}$ \\
& $\mathrm{X} \pm \mathrm{SD}$ & $\mathrm{X} \pm \mathrm{SD}$ & $\mathrm{t}$ & 0.62 \\
\hline Organizational Stress & $3.19 \pm 0.35$ & $3.22 \pm 0.35$ & -0.49 & 0.00 \\
Employee Performance & $4.46 \pm 0.57$ & $4.10 \pm 0.52$ & 2.96 & 0 \\
\hline
\end{tabular}

While no significant differences were found between marital statuses in terms of organizational stress ( $\mathrm{tOS}=-0.49$, $\mathrm{p}>0.05)$, significant differences were found between marital statuses in terms of employee performance $(\mathrm{tEP}=2.96$, $\mathrm{p}<0.05$, mean $\mathrm{EP}=4.46$ ). Married employees reported higher scores than singles (Table 3). 
Table 4. Differences between Educational Statuses in terms of organizational stress and employee performance

\begin{tabular}{lccccc}
\hline Scale & Undergraduate & Master & Doctorate & \\
& $(n=75)$ & $(n=13)$ & $(n=8)$ & $\mathrm{F}$ & $\mathrm{P}$ \\
& Ort. $\pm \mathrm{Ss}$ & Ort. $\pm \mathrm{Ss}$ & $\mathrm{Ort.} . \mathrm{Ss}$ & & \\
\hline Organizational Stress & $3.21 \pm 0.34$ & $3.09 \pm 0.37$ & $3.22 \pm 0.43$ & 0.65 & 0.52 \\
Employee Performance & $4.42 \pm 0.50$ & $4.02 \pm 0.77$ & $4.25 \pm 0.78$ & 2.87 & 0.62 \\
\hline
\end{tabular}

No significant differences were found between educational statuses in terms of organizational stress and employee performance $(\mathrm{FOS}=0.65, \mathrm{p}=0.52>0.05 ; \mathrm{FEP}=2.87, \mathrm{p}=0.62>0.05)$ (Table 4).

Table 5. Differences between monthly incomes in terms of organizational stress and employee performance

\begin{tabular}{lccccc}
\hline Scale & Low & Medium & High & & \\
& $(n=27)$ & $(n=47)$ & $(n=22)$ & $\mathrm{F}$ & $\mathrm{P}$ \\
& $\mathrm{X} \pm \mathrm{SD}$ & $\mathrm{X} \pm \mathrm{SD}$ & $\mathrm{X} \pm \mathrm{SD}$ & & \\
\hline Organizational Stress & $3.15 \pm 0.44$ & $3.21 \pm 0.31$ & $3.24 \pm 0.34$ & 0.46 & 0.62 \\
Employee Performance & $4.31 \pm 0.54$ & $4.36 \pm 0.63$ & $4.36 \pm 0.51$ & 0.06 & 0.93 \\
\hline
\end{tabular}

No significant differences were found between monthly incomes in terms of organizational stress and employee performance $(\mathrm{FOS}=0.46, \mathrm{p}=0.62>0.05 ; \mathrm{FEP}=0.06, \mathrm{p}=0.93>0.05)$.

Table 6. Differences between age groups in terms of organizational stress and employee performance

\begin{tabular}{lcccccc}
\hline Scale & $\begin{array}{c}24-33 \\
(n=48)\end{array}$ & $\begin{array}{c}34-43 \\
(n=24)\end{array}$ & $\begin{array}{c}44 \text { and over } \\
(n=24)\end{array}$ & $\mathrm{F}$ & $\mathrm{P}$ & Differences \\
& $\mathrm{X} \pm \mathrm{SD}$ & $\mathrm{X} \pm \mathrm{SD}$ & $\mathrm{X} \pm \mathrm{SD}$ & & & \\
\hline $\begin{array}{l}\text { Organizational Stress } \\
\begin{array}{l}\text { Employee } \\
\text { Performance }\end{array}\end{array}$ & $3.25 \pm 0.34$ & $3.06 \pm 0.37$ & $3.23 \pm 0.34$ & 2.55 & 0.08 & $(24-33)-(34-43)-(44>)$ \\
\hline
\end{tabular}

While no significant differences were found between age groups in terms of organizational stress, significant differences were found between age groups in terms of employee performance (FOS $=2.55, p=0.08>0.05$; $\mathrm{FEP}=4.92, \mathrm{p}=0.00<0.05)$. According to Tukey test, applied to determine which group caused the difference, employees between the ages of 34-43 years (mean=4.54) reported higher scores than those between 24-33 years and 44 and over (Table 6).

Table 7. Correlation between organizational stress and employee performance

\begin{tabular}{llcc}
\hline & \multicolumn{3}{c}{ Employee Performance } \\
\hline & $\mathrm{N}$ & $\mathrm{R}$ & $\mathrm{p}$ \\
\hline Organizational Stress & 96 & -0.06 & 0.51 \\
\hline
\end{tabular}

No significant correlation was found between organizational stress and employee performance (rOS $=-0.06$, $\mathrm{p}>0.05$ ) (Table 7). 


\section{Conclusion and Discussion}

According to analyzed data, no significant differences were found between genders in terms of organizational stress and employee performance of employees working in provincial directorate of youth and sport. In the literature, while the results of some studies are parallel to our findings in terms of gender (Gulluoglu, 2012; Kilic, Yumusak, \& Yildiz, 2013; Ozkaya, Yakin, \& Ekinci, 2008; Uzum, 2010), some studies show that female employees report higher scores than males in terms of organizational stress and employee performance (Can, 2010; Michael, Stalikas, Kallia, Karagianni, \& Christine, 2009; Bayik, Ozsoy, Ardahan, Ozkahraman, \& Iz, 2006; Ergun, 2008; Yurtseven, 2016). According to another result, no significant differences were found between marital statuses in terms of terms of organizational stress and employee performance of employees working in provincial directorate of youth and sport. In the studies of Ergun (2008), Ozkaya, Yakin and Ekinci (2008), Uzum (2010), Dereli (2010) and Akbas (2007) no significant differences were found between genders, and these results have parallels with our findings. In contrast with these results, married employees reported higher scores in the studies in nurses by Karahan, Gurpinar, and Ozyurek (2007) and in administrators by Yurtseven (2016), and these results are parallel to our findings.

No significant differences were found between age groups in terms of organizational stress. The findings of Ergun (2008), conducted in employee of health business, supported the results of our study. In contrast to this, Karahan et al. (2007) found statistically significant differences between age groups. In study in which academician participated, Yildirim and Tasmektepgil (2011) found significant differences between age groups. These results supported our findings. It was found that educational status had no impact on organizational stress. The findings of some research in which the differences between educational statuses were examined, supported our results (Gulloglu, 2012; Ergun, 2008; Uzum, 2010). However, Yurtseven (2016) found significant differences between educational statuses, and the results showed that employees having master degree had higher scores than others.

In this study, no significant differences were found between genders in terms of employee performance. The study results of Ergun (2008) in which the differences between genders were examined in terms of employee performance supported our findings. Similarly, Cengiz (2008) found no significant differences between genders in terms of employee performance of employees working in hotels.

Significant differences were found between marital statuses in terms of employee performance in favor of married employees. Married employees reported higher scores than singles. While Ergun (2008) found significant differences between marital statuses, Cengiz (2008) and Senturk and Tekin (2015) found no significant differences between married and single employees in terms of performance. It was found that age was a factor in determining employee performance. In another word, employee performance can vary by age groups. However, Cengiz (2008) found no significant differences between age groups.

Correlation analysis displayed that no significant relationship existed between organizational stress and employee performance in our sample. It can be said that organizational stress is not an impact on the employee performance of our study sample. However, Turunc and Celik (1987) found positive correlation between performance and stress.

Collected data from employees was analyzed. It was reported that data displayed normal distribution when Skewness and Kurtosis values of Organizational Stress and Employee Performance were examined. No significant differences were found between genders in terms of both organizational stress and employee performance. This result showed that both female and male employees had the same level organizational stress and employee performance scores of female and male employees were found to be close to each other. According to $t$ test results, no significant differences were found between marital statuses, however, married employees reported higher scores than singles. It can be said that both married and single employees have organizational stress arising from the institution. It can be interpreted that regular family life and having responsibilities are effective in the differences between marital statuses in terms of employee performance.

No significant differences were found between educational statuses in terms of organizational stress and employee performance of the participants. It can be said that educational level is not an impact on organizational stress and employee performance. ANOVA test showed that no significant differences existed between monthly incomes in terms of organizational stress and employee performance. It can be interpreted that no significant differences exist between monthly incomes because there are no performance-based wage policy and accordingly there is no competition between employees. 
Significant differences were found between age groups in terms of employee performance while no significant differences were found in terms of organizational stress. It was found that employees aged between 34-43 years had higher scores than other age groups in terms of employee performance. This result can be interpreted that these employees have more mature opinions mentality and may work conspiratorially. According to age group results, employee performance of employees aged between 24-33 years may be affected because they may have adaptation problems and work conspiratorially. For the employees aged over 44 years, it can be said that they may have reached the burnout level; correspondingly these employees reported lower scores in employee performance. Correlation results showed that no significant relationship existed between organizational stress and employee performance.

\section{References}

Akal, Z. (1992). Isletmelerde performans olcum ve denetimi: Cok yonlu performans gostergeleri. Ankara: MPM Yayinlari.

Akbas, G. (2007). Servis hemsirelerinin stres ve motivasyon duzeylerinin belirlenmesi (Unpublished master's thesis). Halic University, Istanbul, Turkey.

Arrington, P. (2008). Stress At Work: How Do Social Workers Cope? Washington: National Association of Social Workers.

Baransel, A. (1993). Cagdas yonetim dusuncesinin evrimi. Istanbul: Avciyol Yayinlari.

Basaran, İ. E. (1984). Yonetime giris. Ankara: Ankara Universitesi Egitim Fakultesi.

Bastug, G., Pala, A., Kumartasli, M., Gunel, I., \& Duyan, M. (2016). Investigation of the relationship between organizational trust and organizational commitment. Universal Journal of Educational Research, 4(6), 1418-1425. https://dx.doi.org/10.13189/ujer.2016.040619

Bayik, A., Ozsoy, S. A., Ardahan, M., Ozkahraman, S., \& Iz, F. B. (2006). Kadinların stres verici yasam olaylariyla karsilasma durumlari. Ataturk Universitesi Hemsirelik Yuksekokulu Dergisi, 9(2), 1-12.

Blaug, R., Kenyon, A., \& Lekhi, R. (2007). Stress at Work. London: The Work Foundation.

Buyukozturk, S. (2012). Sosyal bilimler icin veri analizi el kitabi. Ankara: Pegem Akademi.

Can, S. (2010). Organizational stressors for the students teachers in State Universities. Procedia Social and Behavioral Sciences, 2(2), 4853-4857. https://dx.doi.org/10.1016/j.sbspro.2010.03.783

Cengiz, S. (2008). Otel isletmelerinde çalisanlarin orgutsel bagliliginin isgoren performansi uzerindeki etkileri (Unpublished master's thesis). Adnan Menderes University, Aydin, Turkey.

Cicei, C. C. (2012). Occupational stress and organizational commitment in Romanian public organizations. Social and Behavioral Sciences, 33, 1077-1081. https://dx.doi.org/10.1016/j.sbspro.2012.01.288

Cakici, A., \& Dogan, S. (2014). Orgutsel sinizmin is performansina etkisi: Meslek yuksekokullarinda bir arastirma. Dogus Universitesi Dergisi, 15(1), 79-89.

Cokluk, O., Sekercioglu, G., \& Buyukozturk, S. (2010). Sosyal bilimler icin cok degiskenli istatistik: SPSS ve LISREL uygulamalari. Ankara: Pegem Akademi.

Col, G. (2008). Algilanan guclendirmenin isgoren performansi uzerine etkileri. Dogus Universitesi Dergisi, 9(1), $35-46$.

Daft, R. L. (1991). Management (2nd ed.). Orlando: The Dryden Press.

Dereli, E. (2010). The effect of organizational sources of stress on employees' job-related affective well-being (Unpublished master's thesis). Marmara University, Istanbul, Turkey.

Didymus, F. F., \& Fletcher, D. (2014). Swimmers' experiences of organizational stress: Exploring the role of cognitive appraisal and coping strategies. Journal of Clinical Sport Psychology, 8, 159-183. https://dx.doi.org/10.1123/jcsp.2014-0020

Dogu, G., \& Yilmaz, B. (2015). Study on relationship between working performance and organizational silence among employees of Central Organization of Ministry of Youth and Sports. International Journal of Science Culture and Sport, 3(4), 47-58.

Ergun, G. (2008). Saglik isletmelerinde orgutsel stresin isgüçü performansiyla etkilesiminin incelenmesi. Dokuz Eylul University, Izmir, Turkey. 
Fletcher, D., \& Hanton, S. (2003). Sources of organizational stress in elite sports performers. The Sport Psychologist, 17, 175-195. https://dx.doi.org/10.1123/tsp.17.2.175

Gulluoglu, O. (2012). Yerel televizyon calisanlarinin orgutsel stres faktorleri: Kayseri ilinde bir arastirma. Istanbul Universitesi Iletisim Fakultesi Dergisi, 2(43), 77-104.

Ilgar, L. (1996). Egitim yonetimi, okul yonetimi, sinif yonetimi. Istanbul: Beta Yayincilik.

Karahan, A., Gurpinar, K., \& Ozyurek, P. (2007). Hizmet sektorundeki isletmelerin orgut ici stres kaynaklari: Afyon ili merkezindeki hastanelerde calisan cerrahi hemsirelerin stres kaynaklarinin belirlenmesi. Ekonomik ve Sosyal Arastirmalar Dergisi, 3(1), 27-44.

Kilic, R., Yumusak, S., \& Yildiz, H. (2013). Banka calısanlarinin maruz kaldiklari bireysel ve orgutsel stres kaynaklari arasindaki iliskilerin incelenmesi. Eskisehir Osmangazi Universitesi IIBF Dergisi, 8(2), 71-92.

Kirkman, B. L., \& Rosen, B. (1999). Beyond self-management: Antecedents and consequences of team empowerment. Academy of Management Journal, 42, 58-74. https://dx.doi.org/10.2307/256874

Kline, R. B. (2005). Principles and practice of structural equation modeling: Methodology in the social sciences. New York, NY: Guilford Press.

Koc, M. (1994). K.T.Ü. Fatih Egitim Fakultesi birinci sinif ogrencilerinin mesleki secimlerine etki eden faktorlerin belirlenmesi. Cagdas Egitim Dergisi, 19, 204-216.

Kristiansen, E., Halvari, H., \& Roberts, G. C. (2012). Organizational and media stress among professional football players: Testing an achievement goal theory model. Scandinavian Journal of Medicine and Science in Sports, 22, 569-579. https://dx.doi.org/10.1111/j.1600-0838.2010.01259.x

Kristiansen, E., Murphy, D., \& Roberts, G. C. (2012). Organizational stress and coping in U.S. Professional $\begin{array}{lllll}\text { soccer. Journal of Applied Sport Psychology, 24, 223. } & \text { 207 }\end{array}$ https://dx.doi.org/10.1080/10413200.2011.614319

Michael, G., Stalikas, A., Kallia, H., Karagianni, C., \& Christine, K. (2009). Gender differences in experiencing occupational stress: The role of age, education and marital status. Stress and Health, 25(5), 397-404. https://dx.doi.org/10.1002/smi.1248

Onay, M., Suslu, Z. H., \& Kilci, S. (2011). Iletisim tarzinin ve sozsuz iletisimin calisanların is performansina etkisi: Posta dagiticilari ve hemsireler uzerine bir arastirma. Organizasyon ve Yonetim Bilimleri Dergisi, 3(1), 102-113.

Ogut, A., \& Kaplan, M. (2015). Saglik sektorunde psikolojik sermayenin is performansı uzerindeki etkisi. Selcuk Universitesi Iktisadi ve Idari Bilimler Fakultesi Sosyal ve Ekonomik Arastirmalar Dergisi, 15(30), 86-99.

Ozkaya, M. O., Yakin, V., \& Ekinci, T. (2008). Stres duzeylerinin calisanlarin is doyumu uzerindeki etkisi: Celal Bayar Universitesi calisanlari uzerine ampirik bir arastirma. Celal Bayar Universitesi Iktisadi ve Idari Bilimler Fakultesi Yonetim ve Ekonomi Dergisi, 15(1), 163-180.

Ozutku, H., Agca, V., \& Cevrioglu, E. (2008). Lider-uye etkilesim teorisi cercevesinde, yonetici-ast etkilesimi ile orgutsel baglilik boyutlari ve is performansi arasindaki iliski: Ampirik bir inceleme. Iktisadi ve Idari Bilimler Dergisi, 22(2), 193-210.

Rabinowitz, S. S. (1987). Facets of role conflict, role-specific performance, and organizational level within the academic career. J Vocational Behav, 30, 72-83. https://dx.doi.org/10.1016/0001-8791(87)90027-3

Suliman, A. M. T. (2001). Work performance: Is it one thingor many things? The multi dimensionality of performance in a Middle Eastern Context. The International Journal of Human Resource Management, 6, 1049-1061. https://dx.doi.org/10.1080/713769689

Senturk, F. K., \& Tekin, Y. (2015). Orgutsel baglilik, orgutsel destek ve is arkadasi desteginin isgoren performansi uzerine etkileri: AVM calisanlari ornegi. Uluslararası Alanya Isletme Fakultesi Dergisi, 7(2), 195-206.

Theorell, T., Perski, A., \& Åkerstedt, T. (1988). Changes in job strain in relation to changes in physiological state. Scand J Work Environ Health, 14, 189-196. https://dx.doi.org/10.5271/sjweh.1932

Turunc, O., \& Celik, M. (2010). Calisanlarin algiladiklari orgutsel destek ve is stresinin orgutsel ozdeslesme ve is performansina etkisi. Yonetim ve Ekonomi, 17(2), 183-206. 
Uzum, H. (2010). Elit sporcularin orgutsel stres duzeyleri ile orgutsel baglilik iliskisinin incelenmesi (Unpublished master's thesis). Abant Izzet Baysal University, Bolu, Turkey.

Uzum, H., Mirzeoglu, N., Polat, E., \& Akpinar, S. (2013). Development of organizational stress scale for athletes. Nigde University Journal of Physical Education and Sport Sciences, 7(2), 137-150.

Yildirim, Y., \& Tasmektepligil, M. Y. (2011). Beden Egitimi ve Spor Yuksekokullarindaki gorevli akademisyen personelin orgutsel stres ve tukenmislik duzeyleri arasindaki iliskinin incelenmesi. Spormetre Beden Egitimi ve Spor Bilimleri Dergisi, 9(4), 131-140.

Yildirim, Y., Tasmektepligil, M. Y., Uzum, H., \& Bulut, D. (2011). Kisa versiyon orgutsel stres olceginin Turkceye uyarlanmasi (Gecerlik ve Guvenirlik Calismasi). Selcuk Universitesi Beden Egitimi ve Spor Bilimleri Dergisi, 13(1), 103-108.

Yildiz, O., Dagdeviren, M., \& Cetinyokus, T. (2008). Isgoren performansinin degerlendirilmesi icin bir karar destek sistemi ve uygulamasi. Gazi Universitesi Muhendislik ve Mimarlık Fakultesi Dergisi, 23(1), 239-248.

Yilmaz, H., \& Karahan, A. (2010). Liderlik davranisi, orgutsel yaraticilik ve isgoren performansi arasindaki iliskilerin incelenmesi: Usak'ta bir arastirma. Yonetim ve Ekonomi, 17(2), 145-158.

Yurtseven, C. N. (2016). Spor isletmelerindeki yoneticilerin orgutsel stres kaynaklarinin incelenmesi (Unpublished master's thesis). Istanbul University, Istanbul, Turkey.

\section{Copyrights}

Copyright for this article is retained by the author(s), with first publication rights granted to the journal.

This is an open-access article distributed under the terms and conditions of the Creative Commons Attribution license (http://creativecommons.org/licenses/by/4.0/). 